\title{
Hyperthermia enhances cytotoxicity of amine oxidase and spermine on drug-resistant LoVo colon adenocarcinoma cells
}

\author{
ENZO AGOSTINELLI ${ }^{1,2}$, FRANCESCA BELLI ${ }^{1,2}$, LAURA DALLA VEDOVA $^{1,2}$, \\ MANUELA MARRA $^{3}$, PASQUALINA CRATERI ${ }^{3}$ and GIUSEPPE ARANCIA ${ }^{3}$
}

\begin{abstract}
${ }^{1}$ Department of Biochemical Sciences 'A. Rossi Fanelli', University of Rome 'La Sapienza', P.le Aldo Moro 5; ${ }^{2}$ National Research Council (CNR), Biology and Molecular Pathology Institutes, P.le Aldo Moro 7, I-00185 Rome;

${ }^{3}$ Department of Technology and Health, National Institute of Health, Viale Regina Elena 299, I-00161 Rome, Italy
\end{abstract}

Received October 31, 2005; Accepted December 13, 2005

\begin{abstract}
Hyperthermia is currently receiving widespread attention when associated with other therapeutic modalities, such as irradiation or chemotherapy, in the treatment of cancer. The occurrence of resistance to cytotoxic pharmacological agents in tumor cells, associated with several phenotypic alterations, is one of the major obstacles to successful anticancer chemotherapy. We investigated a new strategy to overcome multidrug resistance (MDR) cancer cells, using bovine serum amine oxidase (BSAO), which forms toxic products from spermine $\left(\mathrm{H}_{2} \mathrm{O}_{2}\right.$ and aldehydes $)$. The cytotoxicity of the products was evaluated in drug-sensitive (LoVo WT) and multidrug-resistant (LoVo DX) colon adenocarcinoma cells at 37 and $42^{\circ} \mathrm{C}$, using a clonogenic cell survival assay. Cytotoxicity was considerably enhanced at $42^{\circ} \mathrm{C}$. Both toxic species contributed to the thermal enhancement of cytotoxicity induced by BSAO and spermine. Cytotoxicity was eliminated in the presence of catalase and aldehyde dehydrogenase (ALDH). An interesting finding was that $\mathrm{BSAO}$ and spermine at $<1 \mu \mathrm{M}$, which were non toxic at $37^{\circ} \mathrm{C}$, became cytotoxic at $42^{\circ} \mathrm{C}$ and resemble thermosensitizers. Cell survival results and electron microscopy investigations suggest that, at $42^{\circ} \mathrm{C}$, LoVo DX cells are not resistant to the cytotoxic enzymatic oxidation products of spermine, as was already demonstrated in these cells at $37^{\circ} \mathrm{C}$. Moreover, microscopy modifications caused by both toxic products were more pronounced in LoVo DX than in LoVo WT cells, where morphological cytoplasmatic alterations were shown. Our findings suggest that hyperthermia combined with the enzymatic toxic oxidation products of spermine might be a promising anticancer strategy, mainly against MDR tumor cells.
\end{abstract}

Correspondence to: Dr Enzo Agostinelli, Department of Biochemical Sciences 'A. Rossi Fanelli', University of Rome 'La Sapienza', Piazzale A. Moro 5, I-00185 Rome, Italy

E-mail: enzo.agostinelli@uniroma1.it

Key words: polyamines, multidrug resistance, amine oxidase, colon adenocarcinoma, cytotoxicity

\section{Introduction}

Hyperthermia has been used in cancer treatment for many years and it represents the treatment of tumor cells by high temperatures, usually in the range of $42-45^{\circ} \mathrm{C}(1)$. The effect of hyperthermia is particularly beneficial against tumors when used with radiotherapy and chemotherapy (2). The combination of hyperthermia with chemotherapy appears to be useful because localized heating may provide an increase in drug cytotoxicity within a defined target region. The magnitude of the enhancement of drug cytotoxicity by hyperthermia varies with different drugs and with the temperature used (1). In fact, heat induces irreversible biological damage and drug interactions are probably due to several possible targets in cells, such as cellular membrane systems, enzymesproteins and nucleic acids.

Several in vitro and in vivo studies have shown the benefits of hyperthermia in association with radiochemotherapy against various cancer types. Furthermore, hyperthermia is showing promising results in clinical oncology, particularly in Europe $(2,3)$. Considerable progress has been made in recent years in the development of improved methods of heat delivery (3).

Multiple drug resistance has been investigated extensively because it is one of the major obstacles to successful chemotherapy of metastatic diseases $(4,5)$. The development of resistance to one anticancer drug frequently gives rise to resistance to numerous other structurally and functionally unrelated chemotherapeutic compounds (6). This phenomenon, called multidrug resistance (MDR), is associated with a number of phenotypic alterations. Cancer cells with classical MDR usually display decreased intracellular drug accumulation and/or drug distribution (6-8). These modifications are generally due to overexpression of genes which encode membrane-bound transporter proteins, such as a $170-\mathrm{kDa}$ P-glycoprotein (P-gp), multidrug resistance associated protein (MRP) and lung resistance protein (LRP) $(9,10)$. These membrane glycoproteins behave as energy-dependent efflux pumps which are capable of expelling a large variety of xenobiotics, including several anticancer drugs, from cells.

In recent years, numerous in vitro and in vivo studies have been aimed at the development of chemosensitizers to overcome the drug resistance phenotype. Several chemical 
compounds, such as verapamil, etoposide, quinidine, trifluoroperazine and the immunosuppressive agent cyclosporine A, can partially reverse MDR by reducing drug efflux from cells. Various clinical attempts using cyclosporine A (11), verapamil and etoposide have described their roles in reversing or modulating P-gp activity (12). Unfortunately, the high amounts of these substances required to overcome MDR in patients are very toxic, causing undesirable side effects such as hypotension, heart block and myelosuppression. Thus, continued research is required to find more effective clinical applications for overcoming MDR due to P-gp.

Among these methods, a biological strategy to enhance the therapeutic effects of hyperthermia is to use heat together with pharmacological agents that become much more cytotoxic at high temperatures. These compounds, such as cysteamine and aminothiol N-(2-mercaptoethyl)-1,3-propanediamine (WR-1065), defined as thermosensitizers, are not toxic at $37^{\circ} \mathrm{C}$ but become potent cell inactivators at elevated temperatures (13). Another group of drugs, all of which were considered to be heat sensitizers, are the naturally occurring polyamines, putrescine, spermine and spermidine (14).

Our study suggests a new anticancer strategy using bovine serum amine oxidase (BSAO, EC 1.4.3.6), a copper enzyme of $170 \mathrm{kDa} \mathrm{MW}$, which oxidatively deaminates polyamines containing primary amino groups, such as spermidine and spermine. The enzymatic reaction, following a transaminasetype mechanism, produces an aminoaldehyde or an aminodialdehyde respectively, $\mathrm{H}_{2} \mathrm{O}_{2}$ and ammonia $(15,16)$. It also involves dioxygen and water as substrates. In the case of spermine, there is controversy concerning the chemical nature of the aldehyde(s) formed in this reaction; it has been demonstrated that both monoaldehyde and dialdehyde are generated (15), the dialdehyde is unstable, and a further breakdown product appears to be acrolein $\left(\mathrm{CH}_{2}=\mathrm{CHCHO}\right)$ (17). Acrolein was found to be a major toxic product formed from spermidine and spermine by amine oxidase and it accumulated in the plasma of patients with chronic renal failure (18).

Enzymatic oxidation products of polyamines (aldehyde(s) and $\mathrm{H}_{2} \mathrm{O}_{2}$ ) have been implicated in programmed cell death (19), inhibition of DNA and protein synthesis $(20,21)$, apoptosis (22) and inhibition of mammalian cell proliferation (23-25). We previously demonstrated that both $\mathrm{H}_{2} \mathrm{O}_{2}$ and aldehyde(s), formed by purified $\mathrm{BSAO}$ in the presence of exogenous spermine, were involved in cytotoxicity on several cultured cell lines (23-25). An interesting result is that the BSAO/ spermine enzymatic system was able to induce higher cytotoxicity in multidrug-resistant (MDR) cells with overexpression of P-glycoprotein than in their wild-type counterparts (25-27).

In this study, we demonstrate the cytotoxicity induced at $42^{\circ} \mathrm{C}$ by the enzymatic oxidation products of exogenous spermine in drug-sensitive human colon adenocarcinoma (LoVo WT) cells and in multidrug-resistant (LoVo DX) cells that overexpress P-glycoprotein. Since promising results are appearing from clinical investigations involving heat associated with chemotherapy (28), useful effects could also be obtained using heat together with bovine serum amine oxidase in the presence of biogenic amines. The results observed in LoVo DX cells, following this combined strategy, are compared to those obtained in drug-sensitive LoVo WT cells, in order to evaluate whether there are differential effects in cytotoxic responses and whether $\mathrm{H}_{2} \mathrm{O}_{2}$ and aldehyde(s) play a role in the modulation of multidrug resistance. Moreover, cell survival data and both scanning and transmission electron microscopy observations suggest that, at $42^{\circ} \mathrm{C}$, the LoVo multidrugresistant phenotype is not resistant to the cytotoxic enzymatic oxidation products of spermine, as was already demonstrated in these cells at $37^{\circ} \mathrm{C}(25,27)$ and also in multidrug-resistant Chinese hamster ovary $(\mathrm{CHO})$ cells $\left(\mathrm{CH}^{\mathrm{R}} \mathrm{C} 5\right)(26)$. These findings suggest that the purified copper-enzyme, in the presence of spermine and hyperthermia, could prove to be useful in cancer treatment.

\section{Materials and methods}

Purification of BSAO. Bovine blood was withdrawn at a slaughterhouse, mixed with $3.8 \%$ sodium citrate solution (an anticoagulant) and then treated according to Turini et al (29) to purify the copper enzyme amine oxidase. Some modifications were added to the method: a CM-Cellulose column, equilibrated with phosphate-buffer $(0.01 \mathrm{M})$ at $\mathrm{pH} 5.8$, to remove haemoglobin, followed by an AE-Agarose column, in phosphate-buffer $(0.01 \mathrm{M})$ at $\mathrm{pH} 7.2$ to eliminate the blue copper enzyme ceruloplasmin and then two ionic exchange chromatographies were performed using a Q-Sepharose column equilibrated with phosphate-buffer $(0.025 \mathrm{M})$ at pH 6.8 and a Q-Sepharose column, in phosphate-buffer $(0.02 \mathrm{M})$ at $\mathrm{pH} 8.0$. The enzyme was eluted highly purified with an $\mathrm{NaCl}$ gradient. All purification steps were carried out in a cold room, at $4^{\circ} \mathrm{C}$.

The BSAO purification factor was approximately $1,600-$ fold and a single band was obtained on sodium dodecyl sulfate-polyacrylamide gel electrophoresis (SDS-PAGE). Enzymatic activity was assayed spectrophotometrically at $25^{\circ} \mathrm{C}$ by monitoring the formation of benzaldehyde at $250 \mathrm{~nm}$ $\left(\varepsilon=12,500 \mathrm{M}^{-1} \cdot \mathrm{cm}^{-1}\right)$. The specific activity of BSAO was $0.38 \mathrm{IU} / \mathrm{mg}$, with international unit (IU) defined as micromoles of benzylamine oxidized per minute. The protein concentration was determined by absorbance at $280 \mathrm{~nm}$, using an absorption coefficient of $1.741 \cdot \mathrm{g}^{-1} \cdot \mathrm{cm}^{-1}$.

Cell cultures. In this study, a human colon adenocarcinoma cell line (LoVo WT), isolated from a metastatic nodule, and its MDR variant (LoVo DX) were used. Both cell lines were grown in monolayer in Ham's F12 medium (Gibco BRL/Life Technologies Ltd., Paisley, UK) supplemented with $10 \%$ fetal bovine serum (FBS) (Hyclone, Cramlington, UK), 1\% L-glutamine (Gibco BRL/Life Technologies Ltd.), $1 \%$ penicillin $(50 \mathrm{U} / \mathrm{ml})$-streptomycin $(50 \mu \mathrm{g} / \mathrm{ml})$ (Gibco BRL/ Life Technologies Ltd.), 1\% vitamins (Gibco BRL/Life Technologies Ltd.) in a humidified atmosphere of $5 \% \mathrm{CO}_{2}$ in a water-jacketed incubator at $37^{\circ} \mathrm{C}$. The pleiotropic MDR cell line, LoVo DX, was selected for resistance to doxorubicin (DOX) (Adriblastina; Pharmacia \& Upjohn, Milan, Italy) from its drug-sensitive parental LoVo cell line (30). LoVo DX cells are also resistant to other chemotherapeutic agents, such as etoposide and vincristine (31).

Treatments and cell survival experiments. Cell survival experiments were carried out using semiconfluent cells that 
had been incubated for $24 \mathrm{~h}$ at $37^{\circ} \mathrm{C}$ with fresh culture medium. Cells were harvested with $10 \mathrm{mM}$ EDTA in phosphatebuffered saline (PBS) and then by addition of $0.25 \%$ trypsin solution in PBS, washed by centrifugation (2 min, 1,500 g) and resuspended in PBS supplemented with $1 \%$ bovine serum albumin (BSA) (Sigma, St. Louis, MO). Freshly harvested LoVo cells $\left(10^{5} / \mathrm{ml}\right)$ were incubated at $42^{\circ} \mathrm{C}$ for different time intervals in the presence of the following reagents, used alone or in association: $\operatorname{BSAO}(17.06 \mu \mathrm{g} / \mathrm{ml}$ corresponding to $1.00 \times 10^{-4} \mu$ moles $/ \mathrm{ml}$ or $\left.6.98 \times 10^{-3} \mathrm{U} / \mathrm{ml}\right)$, spermine $(6$ and $12 \mu \mathrm{M})$, catalase $(240 \mathrm{U} / \mathrm{ml})$ from bovine liver (Sigma), ALDH (EC 1.2.1.5) from yeast $(0.4 \mathrm{U} / \mathrm{ml})$ and $\mathrm{NAD}^{+}(1.8 \mu \mathrm{g} / \mathrm{ml}$; Boehringer-Mannheim, Mannheim, Germany). Spermine (Fluka, Buchs, Switzerland) was freshly prepared before each experiment and, if present, added last. Cells were then centrifuged, washed twice in PBS-BSA and finally resuspended in $1 \mathrm{ml}$ of PBS-BSA.

Cell suspensions were then plated in tissue culture-coated Petri dishes and incubated at $37^{\circ} \mathrm{C}$. The sensitive colony survival assay that determines the ability of the cells to reproduce and form macroscopic colonies in culture $(>50$ cells), was chosen as the index of cytotoxicity. After 20 days, colonies were fixed with $96 \%$ ethanol, stained with methylene blue and counted manually. Control plating efficiencies at $42^{\circ} \mathrm{C}$ were higher than $82 \%$ and $78 \%$ for LoVo WT and LoVo DX cells, respectively. Percent cell survival was determined as the ratio between the mean number of colonies in treated and control sample.

Scanning electron microscopy. For scanning electron microscopy (SEM), cells were grown to near confluence on glass coverslips. The experiments were carried out by incubating the cells in Ham's F12 medium containing 1\% BSA, without serum, at $42^{\circ} \mathrm{C}$ for different times with BSAO alone $\left(6.98 \times 10^{-3} \mathrm{U} / \mathrm{ml}\right)$, spermine alone $(6$ or $12 \mu \mathrm{M})$, and $\mathrm{BSAO}$ and spermine together. Untreated cells grown at $37^{\circ} \mathrm{C}$ were used as controls. After incubation, cells were washed with F12 medium and then processed for SEM observation as previously described (32). The samples were examined using a Cambridge Stereoscan 360 scanning electron microscope (Cambridge Instruments, Cambridge, UK).

Transmission electron microscopy. For transmission electron microscopy (TEM), cells were grown to near confluence and harvested as above described, then washed, centrifuged and resuspended in $2 \mathrm{ml}$ of $\mathrm{F} 12$ medium-1\% BSA, without serum. The cells were incubated for $60 \mathrm{~min}$ at $42^{\circ} \mathrm{C}$ in the presence of BSAO alone $\left(6.98 \times 10^{-3} \mathrm{U} / \mathrm{ml}\right)$, with exogenous spermine alone ( 6 or $12 \mu \mathrm{M}$ ) or with both BSAO and spermine. Untreated cells grown at $37^{\circ} \mathrm{C}$ were used as controls. After incubation, cells were washed with F12 medium and then processed for TEM observation as previously described (32). TEM observations were performed using a Philips 2085 electron microscope (FEI Company, Eindhoven, The Netherlands).

\section{Results}

It has been demonstrated that polyamines, such as spermine and spermidine, inhibit cell growth in medium containing fetal calf serum. This finding suggested that a toxic effect

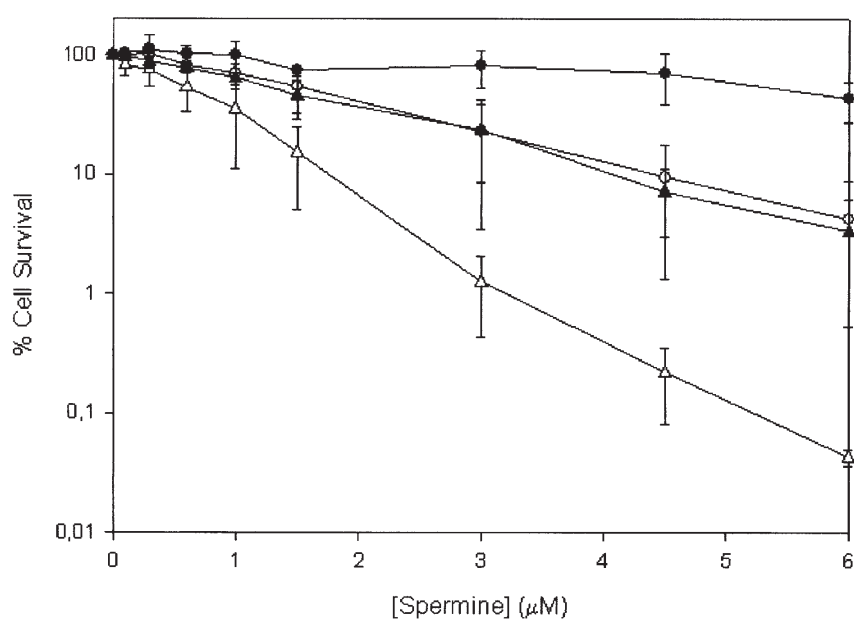

Figure 1. Effect of exogenous spermine concentration on percentage cell survival in the presence of purified BSAO $\left(6.98 \times 10^{-3} \mathrm{U} / \mathrm{ml}\right)$ in LoVo WT (circles) and LoVo DX (triangles) cells during $60 \mathrm{~min}$ at $37^{\circ} \mathrm{C}$ (solid symbols) and $42^{\circ} \mathrm{C}$ (open symbols). Means and standard deviations (SDs) are shown for 2-5 estimations from 4-6 experiments. When not shown, SDs lie within symbols.

was mediated by $\mathrm{H}_{2} \mathrm{O}_{2}$ and aldehyde(s) formed from a copper amine oxidase activity normally present in mammalian serum $(21,33)$. In this study we evaluated by a plating efficiency test and by scanning and transmission electron microscopy, the cytotoxic responses of P-glycoprotein-overexpressing human colon adenocarcinoma LoVo DX cells to the hydrogen peroxide and aldehyde(s) products generated during the enzymatic oxidation reaction of spermine. Fetal bovine serum containing a low copper amine oxidase activity was omitted from the incubation medium in these experiments. In fact, the cytotoxicity induced by purified BSAO, in the presence of exogenous spermine, was assayed in PBS-1\% bovine serum albumin, and it was detected in vitro in MDR cells and compared to that observed in their drug-sensitive LoVo WT counterparts, as a function of spermine concentration as well as exposure time. In addition, the cell survival and morphological changes of sensitive and resistant LoVo cells were investigated by carrying out the treatment in both normo $\left(37^{\circ} \mathrm{C}\right)$ and hyperthermic $\left(42^{\circ} \mathrm{C}\right)$ conditions.

The pleiotropic MDR colon adenocarcinoma LoVo DX cells and the drug-sensitive parental LoVo WT cells were previously characterized for their sensitivity to DOX and for expression of the transporter molecule, P-gp (34). Briefly, LoVo DX cells were approximately 100 times more resistant to DOX than LoVo WT cells. Moreover, LoVo WT cells were negative as concerns the surface P-gp expression analysed by flow cytometry, while MDR variants gave a high level of P-gp labelling. In fact, the intensity of their fluorescent signal increased approximately 2-log as compared to the sensitive cells.

Fig. 1 shows the percent cell survival of both LoVo WT and LoVo DX cells incubated for $60 \mathrm{~min}$ with exogenous spermine $(0-6 \mu \mathrm{M})$ in the presence of BSAO $\left(6.98 \times 10^{-3} \mathrm{U} / \mathrm{ml}\right)$, at $37^{\circ} \mathrm{C}$ or $42^{\circ} \mathrm{C}$. In both cell lines, cytotoxicity increased as a function of spermine concentration up to $6 \mu \mathrm{M}$. There was considerable enhancement of cytotoxicity at $42^{\circ} \mathrm{C}$, compared to $37^{\circ} \mathrm{C}$. At both temperatures, at the highest spermine 

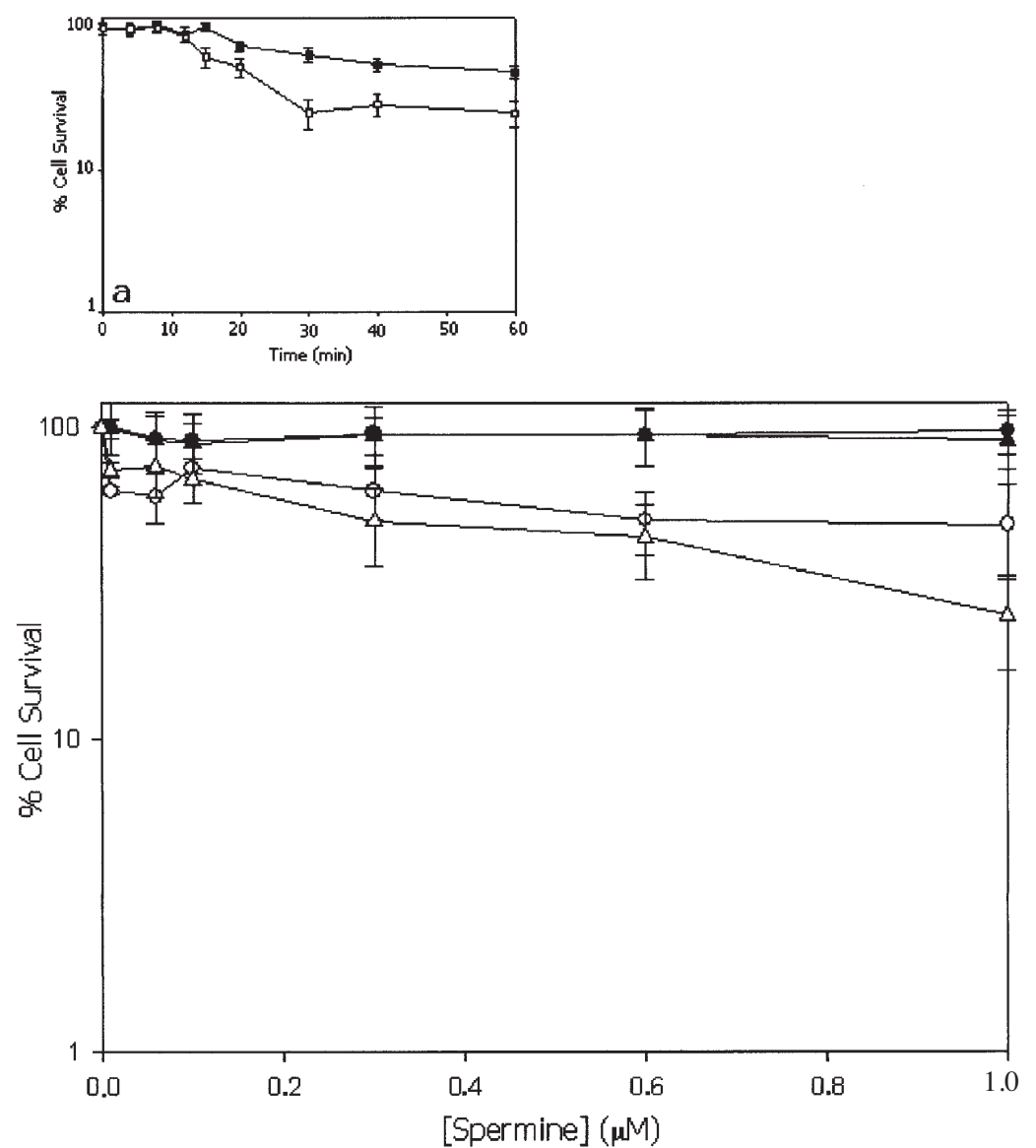

Figure 2. Temperature dependence for cytotoxicity of purified BSAO $\left(6.98 \times 10^{-3} \mathrm{U} / \mathrm{ml}\right)$ as a function of exogenous spermine concentration, up to $1 \mu \mathrm{M}$, on percentage cell survival in LoVo WT (circles) and LoVo DX (triangles) cells during 60 min at $37^{\circ} \mathrm{C}$ (solid symbols) and $42^{\circ} \mathrm{C}$ (open symbols). Insert (a) indicates cytotoxicity in the presence of spermine $1 \mu \mathrm{M}$ during $60 \mathrm{~min}$ of incubation in LoVo WT (solid square) and LoVo DX (open square). Means and SDs are shown for 2-5 estimations from 4-6 experiments. When not shown, SDs lie within symbols.

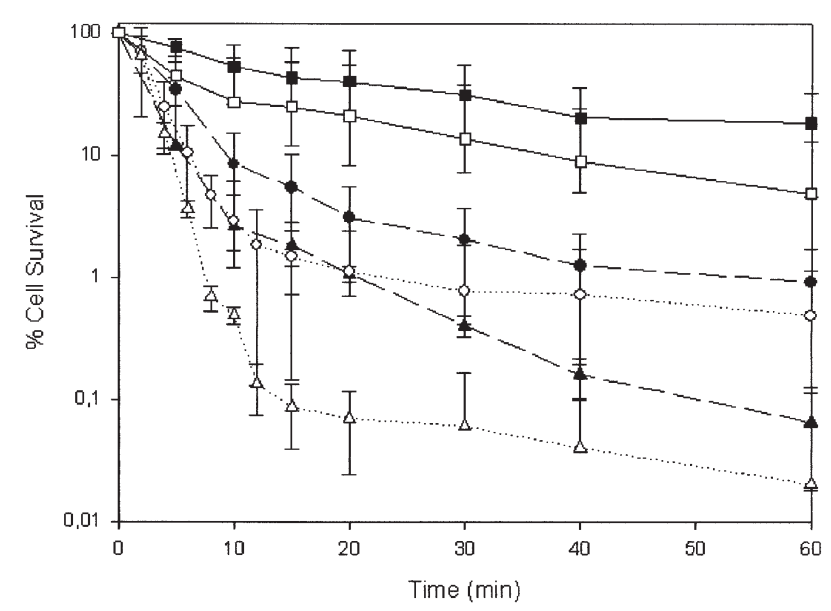

Figure 3. Time course for temperature and spermine concentration dependence on cytotoxicity of BSAO $\left(6.98 \times 10^{-3} \mathrm{U} / \mathrm{ml}\right)$ in the presence of spermine $12 \mu \mathrm{M}$ on percentage cell survival in LoVo WT (circles) and LoVo DX (triangles) cells during $60 \mathrm{~min}$ at $37^{\circ} \mathrm{C}$ (solid symbols) and $42^{\circ} \mathrm{C}$ (open symbols); and at $37^{\circ} \mathrm{C}$ with spermine $6 \mu \mathrm{M}$ in LoVo WT (solid square) and LoVo DX (open square). Means and SDs are shown for 2-5 estimations from 4-6 experiments. When not shown, SDs lie within symbols.

concentration, greater cytotoxicity was observed in MDR cells than in sensitive cells. At $42^{\circ} \mathrm{C}$, the survival of LoVo WT cells was approximately $4 \%$, while only a very low percentage $(<1 \%)$ of LoVo DX cells maintained their viability. At $37^{\circ} \mathrm{C}$, lower cytotoxicity was observed in both LoVo WT and LoVo DX cells. No cytotoxicity was revealed in controls of both cell types, exposed for $60 \mathrm{~min}$ at $37^{\circ} \mathrm{C}$ to either $\mathrm{BSAO}$ alone or spermine alone (data not shown). The effect of $42^{\circ} \mathrm{C}$ hyperthermia on the percentage cell survival versus the time of exposure to BSAO in the presence of exogenous spermine $(6 \mu \mathrm{M})$ was also determined. The percentage cell survival was approximately $2.34 \%$ in LoVo WT and approximately $0.38 \%$ in LoVo DX cells after 60 min of incubation.

Spermine concentrations lower than $1 \mu \mathrm{M}$ in the presence of BSAO were not cytotoxic after $60 \mathrm{~min}$ of incubation at $37^{\circ} \mathrm{C}$ but induced considerable cell killing at $42^{\circ} \mathrm{C}$ (Fig. 2). Consequently, $50 \%$ cell survival occurred at $42^{\circ} \mathrm{C}$ in LoVo WT and $25 \%$ in LoVo DX cells for the spermine concentration of $1 \mu \mathrm{M}$, which was non-toxic at $37^{\circ} \mathrm{C}$. Heat alone, in the absence of the $\mathrm{BSAO} /$ spermine enzymatic system, caused a small decrease $(<20 \%)$ in cell survival (data not shown). However, this small contribution of heat alone to the cytotoxic effect did not account for the magnitude of enhancement of cytotoxicity induced by heat in association with spermine and BSAO. The thermal enhancement increased as a function of spermine concentration, up to $6 \mu \mathrm{M}$ as shown in Fig. 1. Cytotoxicity that was attributed to all of the oxidation products of spermine, $\mathrm{H}_{2} \mathrm{O}_{2}$ and aldehyde(s), was therefore enhanced at $42^{\circ} \mathrm{C}$. 

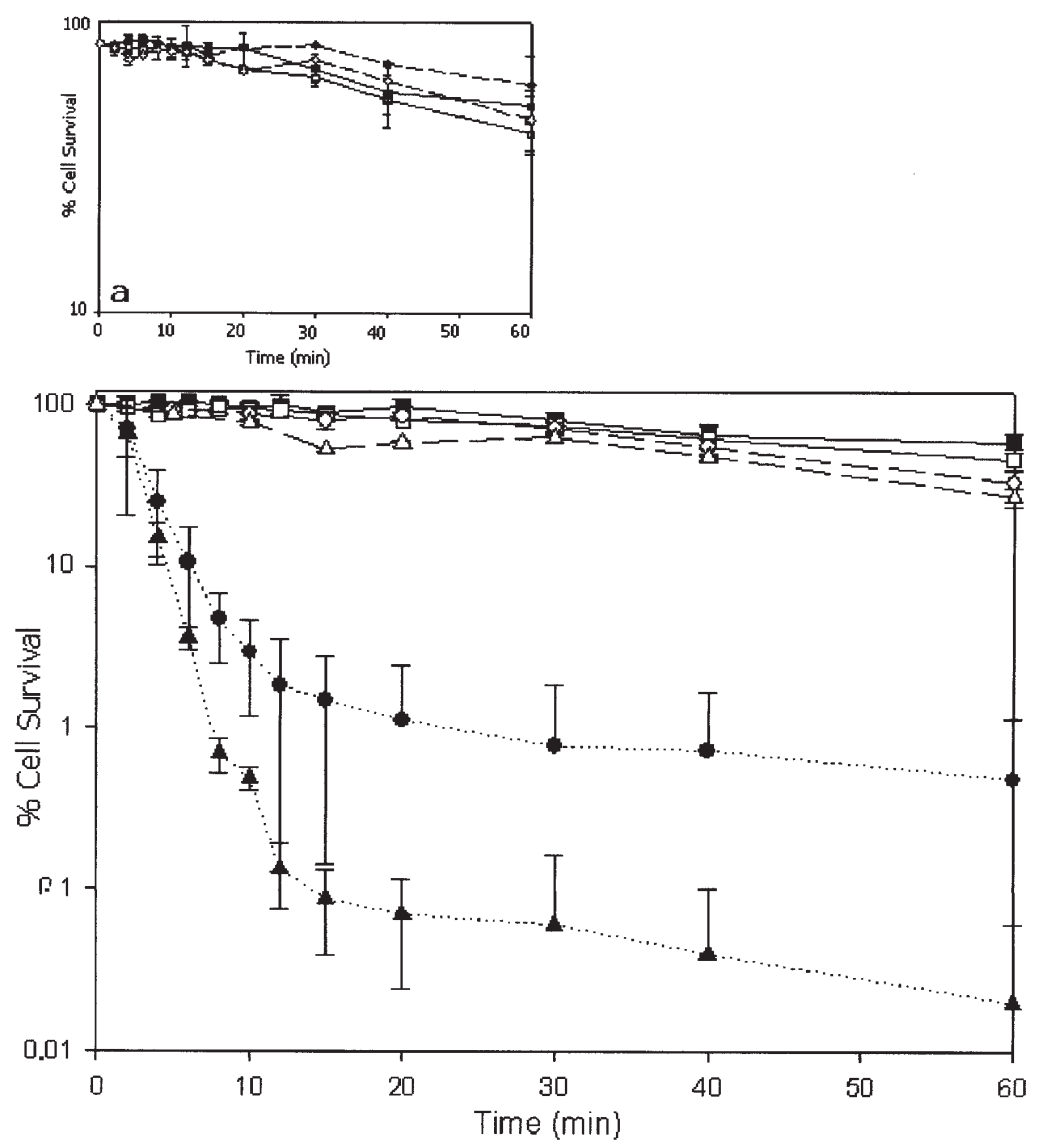

Figure 4. Effect of catalase and ALDH on cytotoxicity induced by BSAO in the presence of spermine. LoVo WT (circles) and LoVo DX (triangles) cells were incubated at $37^{\circ} \mathrm{C}$ with purified BSAO $\left(6.98 \times 10^{-3} \mathrm{U} / \mathrm{ml}\right)$ and exogenous spermine $(12 \mu \mathrm{M})$ without (solid symbols) or with (open symbols with dot) catalase $(240 \mathrm{U} / \mathrm{ml})$; or with both (square symbols) ALDH $(0.4 \mathrm{U} / \mathrm{ml})$ and catalase. The insert (a) reports an extra addition of ALDH $(0.4 \mathrm{U} / \mathrm{ml}$, dotted line) in LoVo WT (solid rhombic) and LoVo DX (open rhombic), compared to the treatment with catalase and ALDH (square symbols). Means and SDs are shown for 2-6 estimations from 4-6 experiments. When not shown, SDs lie within symbols.

Heat enhancement of cytotoxicity induced by BSAO $\left(6.98 \times 10^{-3} \mathrm{U} / \mathrm{ml}\right)$, as a function of exposure time, was demonstrated by adding to the incubation mixture two different exogenous spermine concentrations of 6 and $12 \mu \mathrm{M}$ at $37^{\circ} \mathrm{C}$ and $12 \mu \mathrm{M}$ at $42^{\circ} \mathrm{C}$ (Fig. 3). As expected, it may be seen that the cytotoxic effect in LoVo WT and LoVo DX cells was more marked in the presence of $12 \mu \mathrm{M}$ spermine than $6 \mu \mathrm{M}$ spermine, at $37^{\circ} \mathrm{C}$. Moreover, an increased cytotoxicity was observed in the presence of spermine $12 \mu \mathrm{M}$ after $60 \mathrm{~min}$ of incubation at $42^{\circ} \mathrm{C}$. The higher cytotoxicity in the presence of spermine $12 \mu \mathrm{M}$ was attributed to the formation of an increased amount of $\mathrm{H}_{2} \mathrm{O}_{2}$ and aldehyde(s), during the enzymatic reaction.

A previous study has shown that the cytotoxicity observed during the first 10 min of incubation was mainly attributed to $\mathrm{H}_{2} \mathrm{O}_{2}$ which rapidly crossed the plasma membrane (25). Therefore, to further explain the contribution of each of the enzymatic oxidation products involved in the enhancement by heat, we studied the effect of both exogenous catalase and NAD-dependent ALDH on cytotoxicity caused by $12 \mu \mathrm{M}$ spermine and BSAO, during $60 \mathrm{~min}$ of incubation at $42^{\circ} \mathrm{C}$ (Fig. 4).

As already demonstrated at $37^{\circ} \mathrm{C}$ in $\mathrm{CHO}$ cells $(23,24)$, LoVo cells $(25,27)$ and by other authors $(21)$, we also studied the effect of exogenous catalase (an enzyme which decomposes
$\mathrm{H}_{2} \mathrm{O}_{2}$ ) on the cytotoxicity in LoVo cells at $42^{\circ} \mathrm{C}$ hyperthermia (Fig. 4). The graph shows the percentage cell survival versus the time of exposure to BSAO in the presence of exogenous spermine $12 \mu \mathrm{M}$, without and with $240 \mathrm{EU} / \mathrm{ml}$ of catalase. With purified BSAO and spermine alone, the time-dependent decrease in LoVo cell survival reached the previously detected values after $60 \mathrm{~min}$ of exposure, as also indicated in Fig. 3. On the other hand, in the presence of catalase, a marked reduction of the cytotoxic effect, approximately $65 \%$ in LoVo WT and 55\% in LoVo DX, occurred in both cell lines. These findings suggest that $\mathrm{H}_{2} \mathrm{O}_{2}$, in these experimental conditions, was the enzymatic product mainly responsible for the cell killing in both cell lines (Fig. 4). Moreover, these results also suggested that at $42^{\circ} \mathrm{C}, \mathrm{H}_{2} \mathrm{O}_{2}$ was not the sole toxic agent and that other molecules formed by the enzymatic oxidation of spermine, such as aldehyde(s), dialdehyde and acrolein, were more involved in causing cytotoxicity than at $37^{\circ} \mathrm{C}(25)$. Hyperthermia probably activated both enzymatic oxidation products, enhancing substantially their cytotoxic effect in MDR cells.

The aldehyde(s) formed during the enzymatic reaction caused cytotoxicity in LoVo DX cells, but after longer incubation times. The toxic effect of the aldehyde(s) was more evident in MDR cells compared to the sensitive ones, for longer times ( $\geq 30 \mathrm{~min}$ after treatment with spermine 6 or 

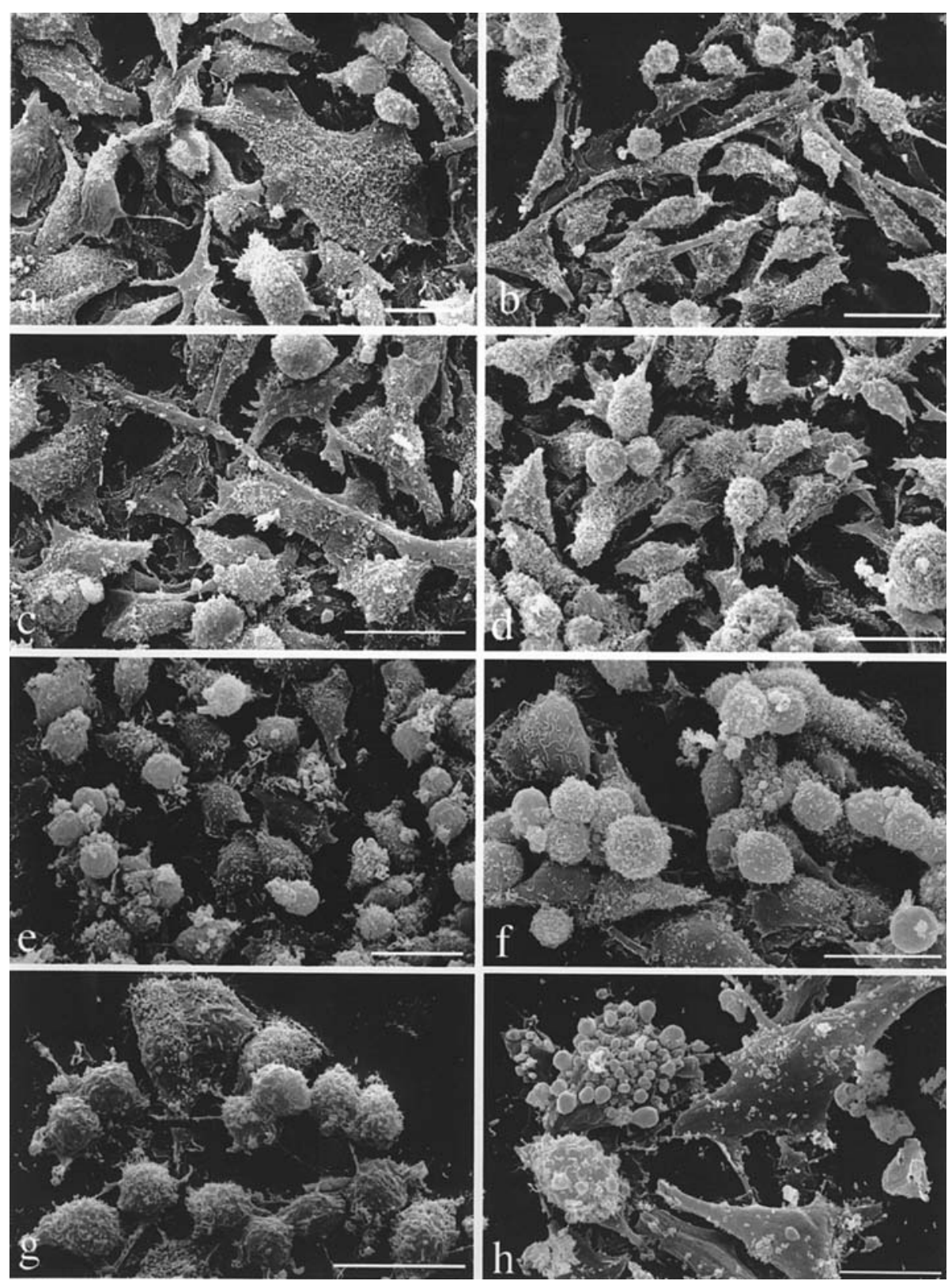

Figure 5. Scanning electron microscopic observations. (a) Control LoVo WT and (b) control LoVo DX cells; (c) LoVo WT and (d) LoVo DX cells after incubation for $1 \mathrm{~h}$ at $42^{\circ} \mathrm{C}$; (e) LoVo WT and (f) LoVo DX cells treated with BSAO and $6 \mu \mathrm{M}$ spermine at $42^{\circ} \mathrm{C} ;(\mathrm{g})$ LoVo WT and (h) LoVo DX cells treated with BSAO and $12 \mu \mathrm{M}$ spermine at $42^{\circ} \mathrm{C}$. LoVo DX cells showed more pronounced alterations, consisting of rounding, detachment and surface blebbing, than their sensitive counterparts, either after heat treatment alone ( $\mathrm{cfr} \mathrm{c}$ with $\mathrm{d}$ ) or after the combined hyperthermia/BSAO-spermine treatment (cfr e with $\mathrm{f}$ and $\mathrm{g}$ with h). Scale bars, $20 \mu \mathrm{m}$.

$12 \mu \mathrm{M}$ at $37^{\circ} \mathrm{C}$ and $<20$ min after treatment with spermine $12 \mu \mathrm{M}$ at $42^{\circ} \mathrm{C}$, Fig. 3). Therefore, a relevant difference in cytotoxicity between MDR and sensitive cells occurred after longer incubation times, under experimental conditions where higher concentrations of $\mathrm{H}_{2} \mathrm{O}_{2}$ and spermine-derived aldehyde(s) had been formed. However, heat also enhanced cell killing in LoVo WT cells but the cytotoxic effect was less pronounced than for LoVo DX cells.

In order to evaluate the contribution of spermine-derived aldehyde(s) in causing cytotoxicity on LoVo cells, the effect of exogenous NAD-dependent ALDH $(0.4 \mathrm{U} / \mathrm{ml})$, in the presence of catalase, on the cytotoxicity induced by $12 \mu \mathrm{M}$ spermine and purified BSAO, was investigated. After addition of both enzymes, cytotoxicity was considerably decreased throughout the 60 min of incubation. However, there was still a gradual decrease in percentage cell survival. This could not be explained by heat inactivation of $\mathrm{ALDH}$ at $42^{\circ} \mathrm{C}$. The addition of another $240 \mathrm{U} / \mathrm{ml}$ of catalase did not prevent this cytotoxic effect (data not shown), while an extra addition of $0.4 \mathrm{U} / \mathrm{ml}$ of NAD-ALDH further decreased cytotoxicity. Therefore, the addition of $0.4 \mathrm{U} / \mathrm{ml}$ of NAD-ALDH was necessary to convert the high amounts of aldehydes or acrolein in acid which had accumulated during the enzymatic oxidation of spermine after longer times.

Scanning (SEM) and transmission (TEM) electron microscopy observations, performed on both wild-type sensitive and multidrug-resistant LoVo cells after treatment with the combination of $\mathrm{BSAO}$ and spermine at $37^{\circ} \mathrm{C}$ and $42^{\circ} \mathrm{C}$, to 

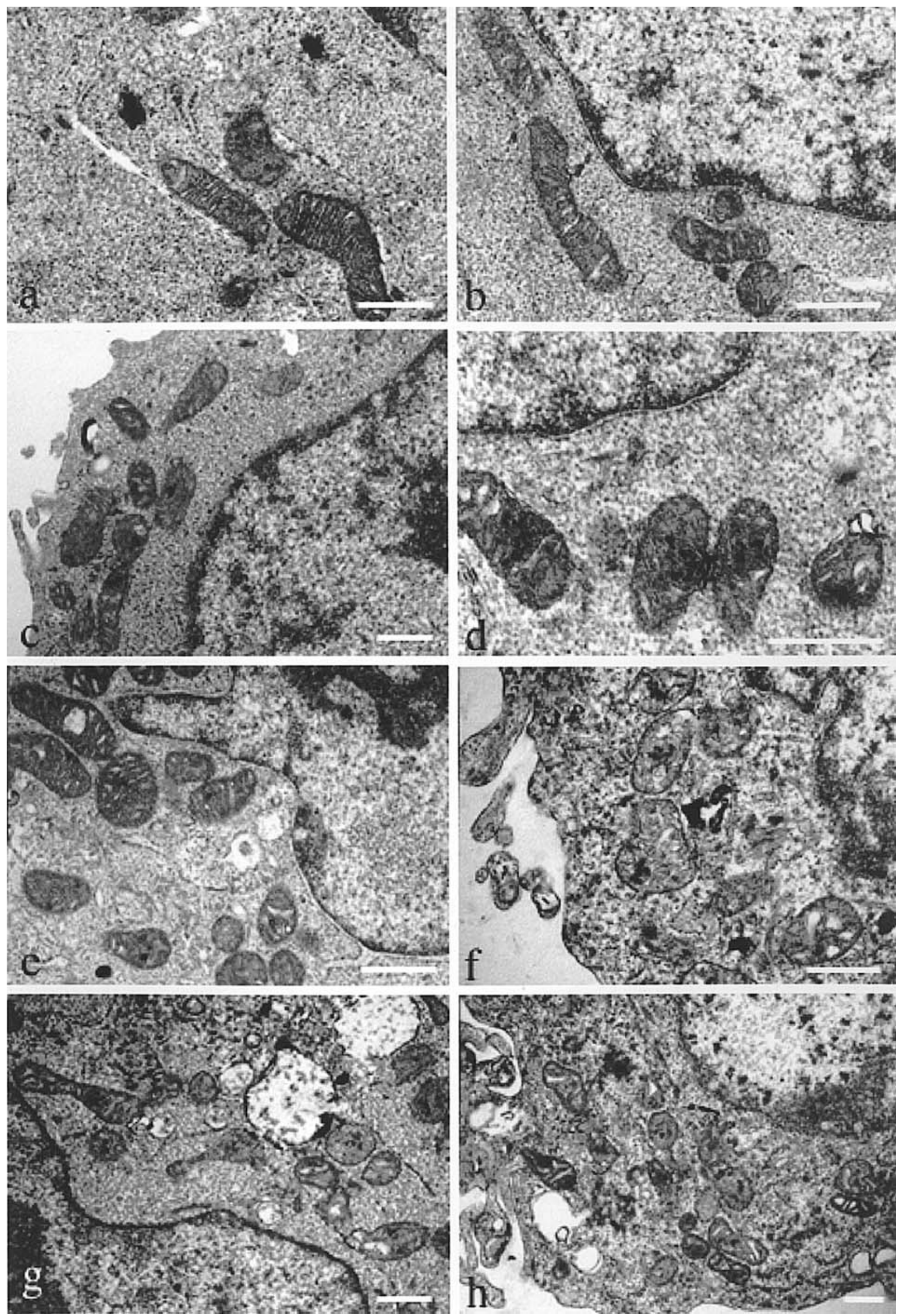

Figure 6. Transmission electron microscopic observations. (a) Control LoVo WT and (b) control LoVo DX cell; (c) LoVo WT and (d) LoVo DX cell after incubation for $1 \mathrm{~h}$ at $42^{\circ} \mathrm{C}$; (e) LoVo WT and (f) LoVo DX cell treated with BSAO and $6 \mu \mathrm{M}$ spermine at $42^{\circ} \mathrm{C}$; (g) LoVo WT and (h) LoVo DX cell treated with $\mathrm{BSAO}$ and $12 \mu \mathrm{M}$ spermine at $42^{\circ} \mathrm{C}$. Alterations of the mitochondrial structure were more evident in treated resistant cells. Moreover, the treatment with BSAO-spermine under hyperthermic conditions produced very severe structural damage, particularly at mitochondrial level (f and h). Scale bars, $0.5 \mu \mathrm{m}$. 
confirm the previously reported (25) higher sensitivity of MDR cells to the oxidation products of spermine, allowed the verification of a close relationship between the extending of morphological and ultrastructural changes and the level of the induced cytotoxic effect. Moreover, TEM analysis indicated the mitochondria as the main intracellular target involved in the enhancement of the cytotoxic action induced by hyperthermia.

Fig. 5a and b shows control untreated LoVo WT and LoVo DX cells, respectively, observed by SEM. No significant morphological difference between the two cell types was detected. Most of the cells showed adherence to the substrate with a typical polygonal shape and the surface covered by randomly distributed microvilli. The treatment with BSAO alone or spermine alone did not induce any appreciable modification (data not shown). After $60 \mathrm{~min}$ of incubation at $42^{\circ} \mathrm{C}$, LoVo WT cells appeared to be substantially unmodified (Fig. 5c) when compared to control cells whereas, interestingly, LoVo DX cells appeared to be more sensitive to the hyperthermic treatment, many cells appearing roundish and tending to detach from the substrate (Fig. 5d).

SEM observations of sensitive and resistant LoVo cells (Figs. 5e and $\mathrm{f}$, respectively) treated with BSAO and $6 \mu \mathrm{M}$ spermine at $42^{\circ} \mathrm{C}$ confirmed the synergic effect of the exposition under hyperthermic conditions (Fig. 1); in both cell lines, the morphological alterations were well evident and particularly LoVo DX cells appeared to be roundish with numerous surface blebs and tended to detach from the substrate. These morphological signs of cell damage were even more evident when using $12 \mu \mathrm{M}$ spermine concentrations and, in this case, LoVo DX cells (Fig. 5h) also appeared to be more affected by the treatment than their wild-type counterparts (Fig. 5g).

Observed by TEM, both control LoVo WT (Fig. 6a) and LoVo DX cells (Fig. 6b) showed a well preserved ultrastructure with the cytoplasm characterized by the presence of numerous mitochondria with an elongated shape and parallel cristae in a dense and uniform matrix. Similar to that observed by SEM analysis, treatment with BSAO or spermine alone did not induce any detectable alteration in the mitochondrial structure in both cell lines (data not shown). The mitochondria of wild-type cells did not show any significant structural change after incubation for $60 \mathrm{~min}$ at $42^{\circ} \mathrm{C}$ (Fig. 6c). Also, the other ultrastructural features appeared to be unmodified after the hyperthermic treatment. Instead, in heat-treated MDR LoVo cells, mitochondria showed a less regular profile with the beginning of intracristal swelling (Fig. 6d). When the hyperthermic treatment was associated with BSAO-spermine administration, an evident differential response between sensitive and drug-resistant cells was observed, according to clonogenic cell survival determinations. In fact, LoVo WT cells treated with BSAO and $6 \mu \mathrm{M}$ spermine at $42^{\circ} \mathrm{C}$ still presented quite a good general ultrastructure (Fig. 6e), even though some mitochondria showed condensed matrix and altered cristae. These modest mitochondrial alterations in LoVo WT cells appear to be very similar to those previously observed in the same cells treated with the same spermine concentration at $37^{\circ} \mathrm{C}(27)$. On the contrary, multidrug-resistant cells exhibited marked modifications (Fig. 6f); in particular, all mitochondria showed altered shape with vacuolized cristae in a rarefied matrix. Finally, treatment with BSAO and $12 \mu \mathrm{M}$ spermine under hyperthermic conditions induced severe alterations in both wild-type (Fig. 6g) and MDR (Fig. 6h) cells, even if such changes appeared to be much more pronounced in resistant cells.

\section{Discussion}

It has been demonstrated that cancer cells are selectively killed by hyperthermia alone (35). Numerous studies evidenced a beneficial effect of hyperthermia when associated with other therapeutic modalities, such as irradiation or chemotherapy, in the treatment of human cancers $(36,37)$. This led researchers to evaluate the clinical potential of hyperthermia using several temperatures (ranging from $40^{\circ} \mathrm{C}$ to $43^{\circ} \mathrm{C}$ ) (1). Localized hyperthermia enhances the cytotoxic process of several antitumoral drugs and has considerable potential in cancer therapy $(38,39)$. This has been explained by a favourable influence on blood flow, cell membrane permeability and drug uptake (40). Hyperthermia could act at the initial stage of the treatment, probably by accelerating the kinetics of the membrane molecular interactions and by favouring drug delivery into the tumor mass (41).

The present study deals with the possible effects of both hydrogen peroxide and aldehyde (produced by the $\mathrm{BSAO}$ /polyamine-spermine enzymatic system) in inducing higher cytotoxicity, at $42^{\circ} \mathrm{C}$, in MDR human colon adenocarcinoma cells compared to the sensitive ones. Rapidly dividing tumor cells contain increased levels of polyamines such as spermine, spermidine and putrescine (42). These high concentrations can be explained by both enhanced putrescine synthesis by ornithine decarboxylase (ODC), the rate-limiting enzyme in polyamine biosynthesis (43), and increased uptake of these polycations (44). Pharmacological molecules with an antiproliferative activity against cancer cells (45), such as $\alpha$ difluoromethylornithine (DFMO) (46) and methylglyoxal-bisguanidylhydrazone $(47,48)$, can inhibit the enzymes involved in the biosynthesis of polyamines (ODC and S-adenosylmethionine decarboxylase, respectively) (49), reducing their levels in cells and resulting in a cytostatic effect $(50,51)$.

The results described in the present report suggest that, in the presence of spermine $6 \mu \mathrm{M}$ for $60 \mathrm{~min}$ of incubation at $42^{\circ} \mathrm{C}$, hydrogen peroxide is the enzymatic product mainly involved in causing cytotoxicity in both LoVo WT and LoVo DX cells (Fig. 2), as already demonstrated at $37^{\circ} \mathrm{C}$ (25). However, both the enzymatic reaction products, $\mathrm{H}_{2} \mathrm{O}_{2}$ and aldehyde(s), were responsible for cytotoxicity, as the addition of catalase alone did not show complete protection. In the presence of both exogenous catalase and NAD-dependent ALDH, cytotoxicity was completely inhibited throughout the incubation at $37^{\circ} \mathrm{C}(25,27)$. At $42^{\circ} \mathrm{C}$, under the same experimental conditions of $\mathrm{BSAO} /$ spermine $6 \mu \mathrm{M}$ with both exogenous enzymes for $60 \mathrm{~min}$ of incubation and in the presence of an extra addition of ALDH $(0.4 \mathrm{U} / \mathrm{ml})$, a high protection against the cytotoxic products was observed. The residual low cytotoxicity $(<15 \%)$ was attributed to heat (Fig. 4). The data obtained suggest that aldehyde(s) formed during the enzymatic oxidation of spermine at $42^{\circ} \mathrm{C}$ were responsible for cytotoxicity that cannot be explained by hydrogen peroxide. Our results clearly show that over- 
expression of P-glycoprotein in LoVo DX cells did not confer any resistance to both cytotoxic products, $\mathrm{H}_{2} \mathrm{O}_{2}$ and sperminederived aldehyde(s). Rather and interestingly, MDR cells appeared to be more sensitive to the enzymatic oxidation products in the presence of higher spermine concentrations $(12 \mu \mathrm{M})$, where a higher amount of $\mathrm{H}_{2} \mathrm{O}_{2}$ and aldehyde(s) was produced, and in hyperthermic conditions. Probably, the enhancement of BSAO-mediated cytotoxicity at $42^{\circ} \mathrm{C}$ is not the result of an increase in enzyme activity at the higher temperature. It has been demonstrated that BSAO shows a characteristic dependence of enzyme activity on temperatures between $35^{\circ} \mathrm{C}$ and $45^{\circ} \mathrm{C}$ with $\mathrm{Q}_{10}$ value of 1.17 (52). This value is lower than that for other enzymes that usually show an approximate $\mathrm{Q}_{10}$ value of 2 . Therefore, in this study, $42^{\circ} \mathrm{C}$ induced only a minor increase in specific activity of BSAO from $0.38 \mathrm{IU} / \mathrm{mg}$ to $0.41 \mathrm{IU} / \mathrm{mg}$, corresponding to only a 1.1 fold increase. Thus, we hypothesize that the great enhancement of the cytotoxic effect observed at $42^{\circ} \mathrm{C}$ can not be explained by an increase only in specific enzyme activity. It could be interpreted by an increased rate of interaction of the enzymatic reaction products with specific target sites, such as DNA or cell plasma membranes, involved in cell death. Cell membranes also represent important sites of cell damage by heat (53). Furthermore, $42^{\circ} \mathrm{C}$ hyperthermia enhances membrane fluidity and, consequently, can increase the transport functions of the plasma membrane (54). Spermine is able to enter the cells by energy-dependent transport across the plasma membrane (55). Thus, exogenous spermine could contribute to the enhancement of heat-induced cytotoxicity (14). However, very low spermine concentrations alone, as used in our experimental conditions, did not induce any cytotoxic effect in either cell line. In fact, the findings clearly showed the essential role of enzymatic oxidation products of polyamines $(24,25,27,33,56)$, rather than polyamines themselves, in causing cytotoxicity (57).

It was observed that the concentrations of spermine necessary to induce cytotoxicity are different in cell lines of various histotype (23-25). An interesting result was that spermine concentrations $\leq 1 \mu \mathrm{M}$ (Fig. 2), in the presence of BSAO, which were not toxic at $37^{\circ} \mathrm{C}$ on LoVo WT and DX cells, became cytotoxic at $42^{\circ} \mathrm{C}$. A similar phenomenon was also observed in $\mathrm{CHO}$ cells (24). BSAO and concentrations of spermine less than $1 \mu \mathrm{M}$ were only cytotoxic at $42^{\circ} \mathrm{C}$ and induced, after $60 \mathrm{~min}$ of incubation, approximately $50 \%$ and $25 \%$ of cell killing on LoVo WT and LoVo DX cells, respectively. The findings suggest a marked enhancement of cytotoxicity on LoVo cells induced by heat, attributed to both enzymatic oxidation products of spermine, $\mathrm{H}_{2} \mathrm{O}_{2}$ and aldehydes. The enzymatic oxidation products of spermine behaved similarly to other thermosensitizers, as aminothiol WR-1065 or cysteamine $(58,59)$.

Hyperthermia alters the membrane permeability to several molecules, including polyamines and certain ions (60). In our study, morphological and ultrastructural modifications were only revealed in MDR cells after mild hyperthermic treatment. In fact, heat-treated LoVo DX cells at $42^{\circ} \mathrm{C}$ for $1 \mathrm{~h}$ exhibited slight alteration of their cellular shape including mitochondrial changes. This could be due to the effect of hyperthermia on certain cytoskeletal protein components and mitochondrial membranes, respectively (41). Therefore, the findings of cell survival studies were supported by scanning and transmission electron microscopy. Both, aldehyde(s) and $\mathrm{H}_{2} \mathrm{O}_{2}$, formed during the enzymatic oxidation of spermine, were able to enter the cells where they caused the cytotoxic effect. This was more pronounced in multidrug-resistant cells, where morphological alterations in the cytoplasmatic organization and ultrastructural modifications were shown; in particular, the structure of mitochondria of LoVo DX cells treated with BSAO and $6 \mu \mathrm{M}$ spermine at $42^{\circ} \mathrm{C}$ was changed dramatically, showing dilated cristae and intracristal swelling. In the presence of BSAO and $12 \mu \mathrm{M}$ spermine, these changes were much more evident and all mitochondria in MDR cells showed a drastically damaged ultrastructure. These structural alterations may be associated with functional modifications as already demonstrated by flow cytometry studies, on LoVo DX cells treated at $37^{\circ} \mathrm{C}(25,61)$. In these experimental conditions, mitochondrial membrane potential (MMP) studies showed that, after treatment with BSAO/spermine enzymatic system, earlier and higher mitochondrial membrane depolarization was found in LoVo DX than in LoVo WT cells. On the basis of these results, it could be hypothesized that LoVo DX cells were more sensitive to $\mathrm{H}_{2} \mathrm{O}_{2}$ and aldehyde(s) because of their higher mitochondrial electron transport chain activity (25). Moreover, it was shown that persistent reactive oxygen species (ROS) overproduction, as a direct consequence of a more active respiratory chain, and membrane hyperpolarization lead to collapsed MMP and hypopolarization, impairment of the mitochondrial function and apoptosis (62). Considering the motives described, it could be hypothesized that LoVo DX cells also produced a high amount of ROS in hyperthermic conditions, which could not be completely removed by endogenous cellular and mitochondrial antioxidant defences, as in normal conditions (63). When LoVo DX cells are treated with BSAO and spermine, they might no longer be able to remove additional reactive oxygen species and lose mitochondrial functionality earlier and to a greater extent than LoVo WT cells. Therefore, the effects of the enzymatic oxidation products of spermine (hydrogen peroxide and aldehydes) were able to induce severe changes in the mitochondrial structure that may not be reflected in the damage of DNA, as already observed (i.e. nuclear condensation and fragmentation), but the alterations, such as dilation of the cristae and disruption of membranes, that are common features of necrosis were mainly observed in MDR cells (64). These findings suggest that such modifications may also have consequences at the level of the cellular membrane and several intracellular proteins.

In view of these results, the use of the amine oxidase enzyme in cancer therapy may be considered. By delivering purified BSAO into cancer cells, cytotoxic products of polyamines oxidation could be produced in situ for their selective killing. The main challenge is how the enzyme can be delivered in vivo to oxidize endogenous polyamines present at high concentrations in cancer cells, to form $\mathrm{H}_{2} \mathrm{O}_{2}$ and aldehyde(s), for possible clinical applications. Bachrach et al were able to obtain enrichment in amine oxidase activity of cells using a purified enzyme preparation entrapped in reconstituted envelopes of Sendai viruses (21). We have obtained the incorporation of bovine serum amine oxidase into liposomal vesicles on the bases of previous experience with liposomal entrapping of superoxide dismutase (65). Besides, macro- 
molecular anticancer drugs can be conjugated with biocompatible polymers which function as carriers and stabilizers, resulting in decreased drug toxicity and increased therapeutic efficacy (66). The results have shown that, by conjugating BSAO with polyethylene glycol hydrogel (PEG), the yield of immobilization was approximately $40 \%$ (67).

Therefore, in the context of therapeutic application, our results demonstrate that the cellular sensitivity of LoVo cells to the toxic products is significantly increased by hyperthermia, mainly in cells expressing the multidrug resistance (MDR) phenotype. Localized hyperthermia could enhance the cytotoxic effects of the enzymatic oxidation products of spermine, within the tumor region, without increasing normal tissue damage. To take advantage of the higher levels of polyamines in cancer cells versus normal tissue, cytotoxic products such as $\mathrm{H}_{2} \mathrm{O}_{2}$ and aldehyde(s) could be generated in situ to induce cytotoxicity by delivering copper amine oxidases into the tumor mass (68). It is our hope that this approach will open new avenues in combating cancer and in treating MDR cancer patients.

\section{Acknowledgements}

This work was partially supported by Ministero della Salute (1\% Fondo Sanitario Nazionale), MIUR-Prin 2003 and 2005 (Cofin) and University of Rome 'La Sapienza'.

\section{References}

1. Hahn GM: Potential for therapy of drugs and hyperthermia. Cancer Res 39: 2264-2268, 1979.

2. Wust P, Hildebrandt B, Sreenivasa G, Rau B, Gellermann J, Riess H, Felix R and Schlag PM: Hyperthermia in combined treatment of cancer. Lancet Oncol 3: 487-497, 2002.

3. Van der Zee J: Heating the patient: a promising approach? Ann Oncol 13: 1173-1184, 2002.

4. Ling V: Multidrug resistance: molecular mechanisms and clinical relevance. Cancer Chemother Pharmacol 40 (suppl): S3-S8, 1997.

5. Gottesman MM: How cancer cells evade chemotherapy? Sixteen Richard and Hinda Rosenthal Foundation Award Lecture. Cancer Res 53: 747-754, 1993.

6. Endicott JA and Ling V: The biochemistry of P-glycoproteinmediated multidrug resistance. Annu Rev Biochem 58: 137-171, 1989.

7. Gervasoni JE Jr, Fields SZ, Krishna S, Baker MA, Rosado M, Thuraisamy K, Hinderburg AA and Taub RN: Subcellular distribution of doxorubicin in P-glycoprotein-positive and -negative drug resistant cell lines using laser-assisted confocal microscopy. Cancer Res 51: 4955-4963, 1991.

8. Arancia G, Calcabrini A, Meschini S and Molinari A: Intracellular distribution of anthracyclines in drug resistant cells. Cytotechnology 27: 95-111, 1998.

9. Gottesman MM and Pastan I: Biochemistry of multidrug resistance mediated by the multidrug transporter. Annu Rev Biochem 62: 385-427, 1993.

10. Izquierdo MA, Scheffer GL, Flens MJ, Schroeijers AB, van der Valk P and Scheper RJ: Major vault protein LRP-related multidrug resistance. Eur J Cancer 32A: 979-984, 1996.

11. Sikic BI: Modulation of multidrug resistance: at the threshold. J Clin Oncol 11: 1629-1635, 1993.

12. Sikic BI, Fisher GA, Lum BL, Halsey J, Beketic-Oreskovic L and Chen G: Modulation and prevention of multidrug resistance by inhibitors of P-glycoprotein. Cancer Chemother Pharmacol 40 (suppl): S13-S19, 1997.

13. Hahn GM: Hyperthemia and Cancer. Plenum Press, New York, 1982.

14. Gerner EW, Holmes DK, Stickney DG, Noterman JA and Fuller DJ: Enhancement of hyperthermia-induced cytotoxicity by polyamines. Cancer Res 40: 432-438, 1980.
15. Tabor $\mathrm{CW}$, Tabor $\mathrm{H}$ and Bachrach $\mathrm{U}$ : Identification of the aminoaldehydes produced by the oxidation of spermine and spermidine with purified plasma amine oxidase. J Biol Chem 239: 2194-2203, 1964.

16. Agostinelli E, Arancia G, Dalla Vedova L, Belli F, Marra M, Salvi $\mathrm{M}$ and Toninello A: The biological functions of polyamine oxidation products by amine oxidases: perspectives of clinical applications. Amino Acids 27: 347-358, 2004.

17. Alarcon RA: Evidence for the formation of the cytotoxic aldehyde acrolein from enzymatically oxidized spermine or spermidine. Arch Biochem Biophys 137: 365-372, 1970.

18. Sakata K, Kashiwagi K, Sharmin S, Ueda S and Igarashi K: Acrolein produced from polyamines as one of the uraemic toxins. Biochem Soc Trans 31: 371-374, 2003.

19. Parchment RE and Pierce GB: Polyamine oxidation, programmed cell death, and regulation of melanoma in the murine embryonic limb. Cancer Res 49: 6680-6686, 1989.

20. Gaugas JM and Dewey DL: Evidence for serum binding of oxidized spermine and its potent $\mathrm{G}_{1}$-phase inhibition of cell proliferation. Br J Cancer 39: 548-557, 1979.

21. Bachrach U, Ash I, Abu-Elheiga L, Hershkovitz M and Loyter A: Fusion-mediated microinjection of active amine and diamine oxidases into cultured cells: effect on protein and DNA synthesis in chick embryo fibroblasts and in glioma cells. J Cell Physiol 131: 92-98, 1987

22. Lindsay GS and Wallace HM: Changes in polyamine catabolism in HL-60 human promyelogenous leukaemic cells in response to etoposide-induced apoptosis. Biochem J 337: 83-87, 1999.

23. Averill-Bates DA, Agostinelli E, Przybytkowski E, Mateescu MA and Mondovì B: Cytotoxicity and kinetic analysis of purified bovine serum amine oxidase in the presence of spermine in Chinese hamster ovary cells. Arch Biochem Biophys 300: 75-79, 1993.

24. Agostinelli E, Przybytkowski E, Mondovì B and AverillBates DA: Heat enhancement of cytotoxicity induced by oxidation product of spermine in chinese hamster ovary cells. Biochem Pharmacol 48: 1181-1186, 1994.

25. Calcabrini A, Arancia G, Marra M, Crateri P, Befani O, Martone A and Agostinelli E: Enzymatic oxidation products of spermine induce greater cytotoxic effects on human multidrugresistant colon carcinoma cells (LoVo) than on their wild-type counterparts. Int J Cancer 93: 43-52, 2002.

26. Lord-Fontaine S, Agostinelli E, Przybytkowski E and AverillBates DA: Amine oxidase, spermine, and hyperthermia induce cytotoxicity in P-glycoprotein overexpressing multidrug resistant Chinese hamster ovary cells. Biochem Cell Biol 79: 112,2001

27. Arancia G, Calcabrini A, Marra M, Crateri P, Artico M, Martone A, Martelli F and Agostinelli E: Mitochondrial alterations induced by serum amine oxidase and spermine on human multidrug resistant tumor cells. Amino Acids 93: 273-282, 2004.

28. Wendtner CM, Abdel-Rahman S, Krych M, Baumert J, Lindner LH, Baur A, Hiddemann W and Issels RD: Response to neoadjuvant chemotherapy combined with regional hyperthermia predicts long-term survival for adult patients with retroperitoneal and visceral high-risk soft tissue sarcomas. J Clin Oncol 20: 3156-3164, 2002.

29. Turini P, Sabatini S, Befani O, Chimenti F, Casanova C, Riccio P and Mondovì B: Purification of bovine plasma amine oxidase. Anal Biochem 125: 294-298, 1982.

30. Grandi M, Geroni C and Giuliani FC: Isolation and characterization of a human colon adenocarcinoma cell line resistant to doxorubicin. Br J Cancer 54: 515-518, 1986.

31. Dolfini E, Dasdia T, Arancia G, Molinari A, Calcabrini A, Scheper RJ, Flens MJ, Gariboldi MB and Monti E: Characterization of a clonal human colon adenocarcinoma line intrinsically resistant to doxorubicin. Br J Cancer 76: 67-76, 1997.

32. Molinari A, Calcabrini A, Crateri P and Arancia G: Interaction of anthracyclinic antibiotics with cytoskeletal components of cultured carcinoma cells (CG5). Exp Mol Pathol 53: 11-33, 1990.

33. Henle KJ, Moss AJ and Nagle WA: Mechanism of spermidine cytotoxicity at $37^{\circ} \mathrm{C}$ and $43^{\circ} \mathrm{C}$ in Chinese hamster ovary cells. Cancer Res 46: 175-182, 1986.

34. Meschini S, Calcabrini A, Monti E, Del Bufalo D, Stringaro A, Dolfini E and Arancia G: Intracellular P-glycoprotein expression is associated with the intrinsic multidrug resistance phenotype in human colon adenocarcinoma cells. Int J Cancer 87: 615-628, 2000 . 
35. Cavaliere R, Ciocatto EC, Giovanella BC, Heidelberger C, Johnson RO, Margottino M, Mondovì B, Moricca G and Rossi-Fanelli A: Selective heat sensitivity of cancer cells. Biochemical and clinical studies. Cancer 20: 1351-1381, 1967.

36. Takahashi T, Horie H, Kojima O and Itoh M: Preoperative combined treatment with radiation, intraluminal hyperthermia, and 5-fluorouracil suppositories for patients with rectal cancer. Jpn J Surg 23: 1043-1048, 1993.

37. Vernon CC, Hand JW, Field SB, Machin D, Whaley JB, van der Zee J, van Putten WL, van Rhoon GC, van Dijk JD, Gonzalez D, Liu FF, Goodman P, et al: Radiotherapy with or without hyperthermia in the treatment of superficial localized breast cancer: results from five randomized controlled trials. International Collaborative Hyperthermia Group. Int J Radiat Oncol Biol Phys 35: 731-744, 1996.

38. Bates DA and Mackillop WJ: The effect of hyperthermia in combination with melphalan on drug-sensitive and drug-resistant CHO cells in vitro. Br J Cancer 62: 183-188, 1990.

39. Dahl O: Mechanisms of thermal enhancement of chemotherapeutic cytotoxicity. In: Hyperthermia and Oncology. Urano M and Douple E (eds). Utrecht: VSP, 4: 9-28, 1994.

40. Reinhold HS and Endrich B: Tumour microcirculation as a target for hyperthermia. Int J Hyperthermia 2: 111-137, 1986

41. Agostinelli E, Arancia G, Calcabrini A, Matarrese P, Mondovì B and Pietrangeli P: Hyperthermia-induced biochemical and ultrastructural modifications in cultured cells. Exp Oncol 17: 269-276, 1995.

42. Bachrach U: Polyamines as indicators of disease activity and response to therapy in cancer patients. In: The Physiology of Polyamines. Vol. 2. Bachrach U and Heimer YM (eds). CRC Press, Boca Raton, FL, pp234-249, 1989.

43. Williams-Ashman HG and Canellakis ZN: Polyamines in mammalian biology and medicine. Perspect Biol Med 22: 421-453, 1979

44. Marton LJ and Pegg AE: Polyamines as targets for therapeutic intervention. Annu Rev Pharmacol Toxicol 35: 55-91, 1995.

45. Seiler N, Duranton B and Raul F: The polyamine oxidase inactivator MDL 72527. Prog Drug Res 59: 1-40, 2002.

46. Seiler N: Thirty years of polyamine-related approaches to cancer therapy. Retrospect and prospect. Part 1. Selective enzyme inhibitors. Curr Drug Targets 4: 537-564, 2003.

47. Metcalf BW, Bey P, Danzin C, Jung M, Casara P and Ververt JP: Catalytic irreversible inhibition of mammalian ornithine decarboxylase (E.C. 4.1.1.17) by substrate and product analogues. J Am Chem Soc 100: 2551-2553, 1978.

48. Wallace HM and Fraser AV: Polyamines analogues as anticancer drugs. Biochem Soc Trans 31: 393-396, 2003.

49. Thomas T and Thomas TJ: Polyamines in cell growth and cell death: molecular mechanisms and therapeutic applications. Cell Mol Life Sci 58: 244-258, 2001.

50. Porter CW and Sufrin JR: Interference with polyamine biosynthesis and/or function by analogs of polyamines or methionine as a potential anticancer chemotherapeutic strategy. Anticancer Res 6: 525-542, 1986.

51. Harari PM, Fuller DJM, Carper SW, Croghan MK, Meyskens FL $\mathrm{Jr}$, Shimm DS and Gerner EW: Polyamine biosynthesis inhibitors combined with systemic hyperthermia in cancer therapy. Int J Radiat Oncol Biol Phys 19: 89-96, 1990.

52. Befani O, Sabatini S, Mateescu MA and Mondovì B: Peculiar effects of temperature and polyvinylalcohol on the activity of bovine serum amine oxidase. Biochem Biophys Res Commun 163: 1168-1174, 1989.
53. Arancia G, Malorni W, Mariutti G and Trovalusci P: Effect of hyperthermia on the plasma membrane structure of Chinese hamster V79 fibroblasts: a quantitative freeze-fracture study. Radiat Res 106: 47-55, 1986.

54. Bates DA, Le Grimellec C, Bates JH, Loutfi A and Mackillop WJ: Effects of thermal adaptation at 40 degrees $\mathrm{C}$ on membrane viscosity and the sodium-potassium pump in Chinese hamster ovary cells. Cancer Res 45: 4895-4899, 1985.

55. Seiler N and Dezeure F: Polyamine transport in mammalian cells: Int J Biochem 22: 211-218, 1990.

56. Bachrach U, Abzug S and Bekierkunst A: Cytotoxic effect of oxidized spermine on Ehrlich ascites cells. Biochim Biophys Acta 134: 174-181, 1967.

57. Ben-Hur E, Prager A and Riklis E: Enhancement of thermal killing by polyamines. Survival of Chinese hamster cells. Int J Cancer 22: 602-606, 1978.

58. Nagele A, Meier T and Issels RD: Thermosensitization, depletion of glutathione, and modulation of polyamine catabolism in CHO cells by the aminothiol WR-1065. Prog Pharm Clin Pharm 8: 176-180, 1990.

59. Kapp DS and Hahn GM: Thermosensitization by sulfhydryl compounds of exponentially growing Chinese hamster cells. Cancer Res 39: 4630-4635, 1979.

60. Gerner EW, Cress AE, Stickney DG, Holmes DK and Culver PS: Factors regulating membrane permeability alter thermal resistance. Ann NY Acad Sci 335: 215-233, 1980.

61. Salvioli S, Ardizzoni A, Franceschi C and Cossarizza A: JC-1, but not DiOC6(3) or rhodamine 123, is a reliable fluorescent probe to assess delta psi changes in intact cells: implications for studies on mitochondrial functionality during apoptosis. FEBS Lett 411: 77-82, 1997.

62. Banki K, Hutter E, Gonchoroff NJ and Perl A: Elevation of mitochondrial transmembrane potential and reactive oxygen intermediate levels are early events and occur independently from activation of caspases in Fas signalling. J Immunol 162: 1466-1479, 1999.

63. Kowaltowski AJ and Vercesi AE: Mitochondrial damage induced by conditions of oxidative stress. Free Rad Biol Med 26: 463-471, 1999.

64. Bonneau M-J and Poulin R: Spermine oxidation leads to necrosis with plasma membrane phosphatidylserine redistribution in mouse leukemia cells. Exp Cell Res 259: 23-34, 2000.

65. Agostinelli E, Riccio $\mathrm{P}$, Muccigrosso J, Befani $\mathrm{O}$ and Mondovì $\mathrm{B}$ : On the handling of amine oxidase activity as a biochemical tool: perspectives. In: Perspectives in Polyamine Research. Perin A, Scalabrino G, Sessa A and Ferioli ME (eds). Wichtig Editor, Milan, pp17-19, 1988.

66. Maeda H, Seymour LW and Miyamoto Y: Conjugates of anticancer agents and polymers: advantages of macromolecular therapeutics in vivo. Bioconjug Chem 3: 351-362, 1992.

67. Demers N, Agostinelli E, Averill-Bates DA and Fortier G: Immobilization of native and poly(ethylene glycol)-treated ('PEGylated') bovine serum amine oxidase into a biocompatible hydrogel. Biotechnol Appl Biochem 33: 201-207, 2001.

68. Averill-Bates DA, Cherif A, Agostinelli E, Tanel A and Fortier G: Anti-tumoral effect of native and immobilized bovine serum amine oxidase in a mouse melanoma model. Biochem Pharmacol 69: $1693-1704,2005$ 